\title{
SYNTHESIS OF SOME RHODANINE DERIVATIVES
}

\author{
Ngo Thi Thuy Duong ${ }^{(1)}$, Nguyen To Nha ${ }^{(1)}$, Fritz Duus ${ }^{(2)}$, Nguyen Kim Phi Phung ${ }^{(1)}$ \\ (1) University of Science, VNU-HCM \\ (2)Roskilde University, Denmark
}

(Manuscript Received on January $08^{\text {th }}, 2009$, Manuscript Revised May $20^{\text {th }}, 2009$ )

\begin{abstract}
Thioketone and enthiol compounds were synthesized from methyl isothiocyanate and ethyl mercaptoacetate through thionation with $P_{2} S_{5}$ and acylation with aromatic carboxylic acid chlorides.

Key words: thiocompound, thionation, acylation, synthesis of derivatives of rhodanine, thioketone-enol - ketone-enthiol tautomerism.
\end{abstract}

\section{INTRODUCTION}

Organosulfur compounds are valued not only for their rich and varied chemistry, but also for many important biological properties. Transformation of a carbonyl group to thiocarbonyl group has been an important interest to synthetic organic chemists for many years. In this report, we studied on the transformation carbonyl group to thiocarbonyl group, and then acylated this thio-compound. We also studied on the influence of different substituents on the intramolecular hydrogen bond in these products from acylation and the thioketone-enol ketone-enthiol tautomerism.

In the experiment, 3-methylrhodanine was first synthesized because it could not be commercially obtained. Second, it was converted to 4-thio-3-methylrhodanine by using diphosphorous pentasulfide. And then this thio-compound was acylated with different aromatic carboxylic acid chlorides (ten compounds).

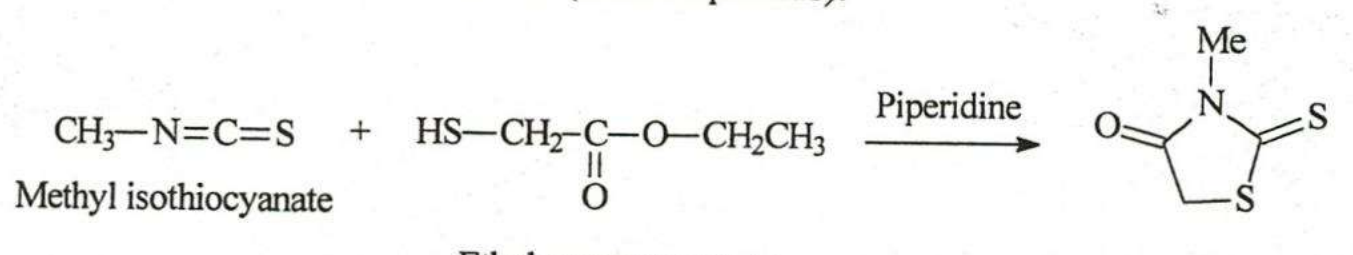

Ethyl mercaptoacetate

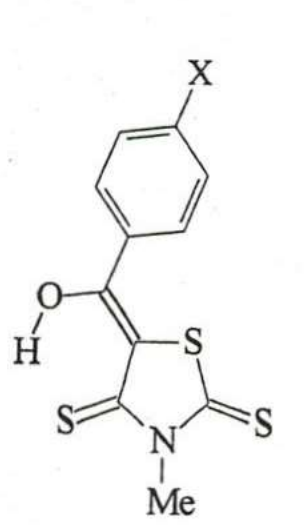

Thioketone (A)

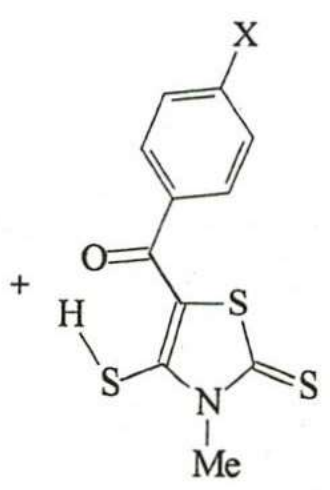

Enthiol (B)
3-Methylrhodanine

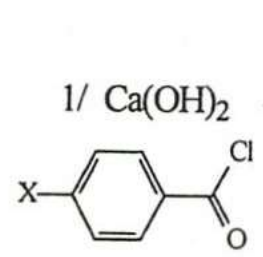

Refluxed at $80-95^{\circ} \mathrm{C} ; 1.5 \mathrm{~h}$

2/ $\mathrm{HCl}$<smiles>CN1C(=S)CSC1=S</smiles>

3-Methyl-4-thiorhodanine

Scheme1. Series of the reactions conducting to the final products 


\section{RESULT AND DISCUSSION}

Two reagents - Diphosphorous pentasulfide $\left(\mathrm{P}_{4} \mathrm{~S}_{10}\right)$ and Lawesson's reagent (LR) - are the most widely used to transform a carbonyl group to thiocarbonyl group. Thionation of ketones to thioketones can be done by $\mathrm{P}_{4} \mathrm{~S}_{10}$, but typically in rather low yield. In recent years Lawesson's reagent (LR) has replaced $\mathrm{P}_{4} \mathrm{~S}_{10}$ as the reagent of choice for many thionations. However, besides its high cost, LR results in the formation of by-products derived from the reagent itself, which cannot be easily removed by column chromatography, making the method more expensive. ${ }^{[1,2,3,4,5,6,7,8]}$

In this paper, we report a procedure for the conversion of ketone into thioketone using diphosphorus pentasulfide with charcoal and zinc dust in 1, 4-dioxane. ${ }^{[9]}$<smiles>S=P12SP3(=S)SP(=S)(S1)SP(=S)(S2)S3</smiles><smiles>C=C=CCCCCCCCCC</smiles>

Diphosphorous pentasulfide $\left(\mathrm{P}_{4} \mathrm{~S}_{10}\right)$<smiles>C=C=C</smiles><smiles>COc1ccc(P(=S)=S)cc1</smiles>

Lawesson's reagent (LR)
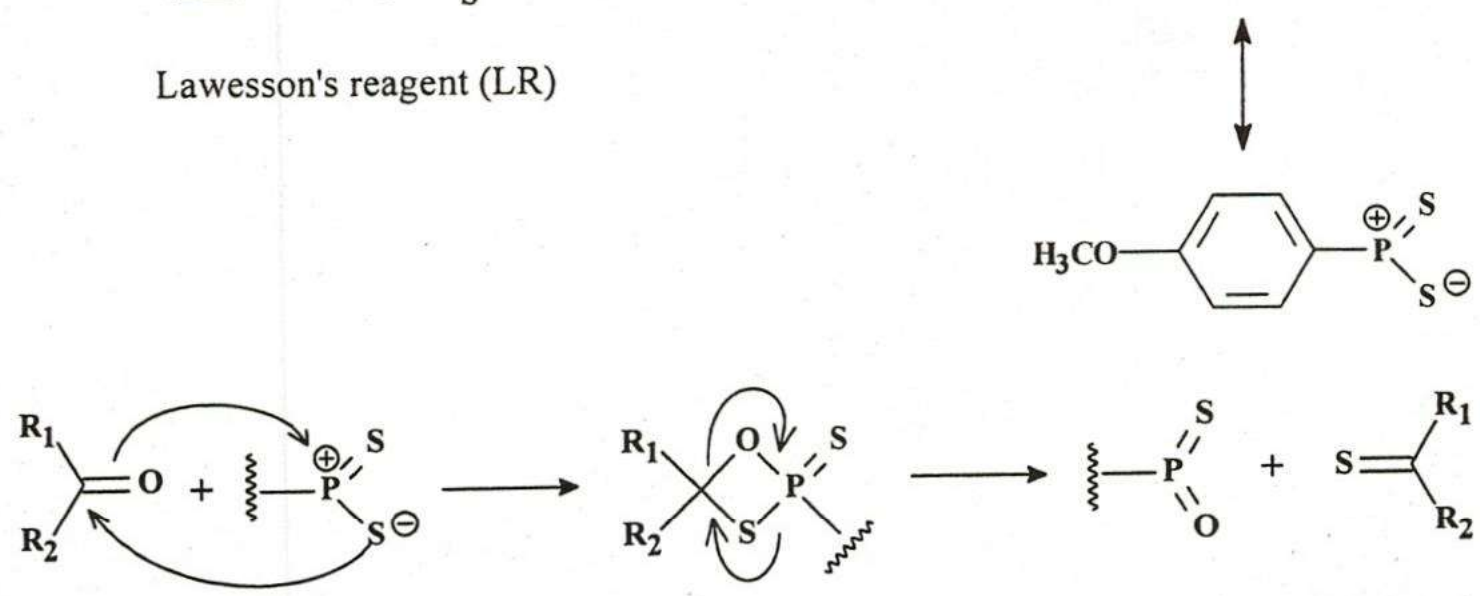

\section{Ketone}

Thioketone

Scheme 2. Mechanism of the conversion of carbonyl group to thiocarbonyl group by $\mathrm{P}_{4} \mathrm{~S}_{10}$ or Lawesson's reagent. ${ }^{[1]}$

The corresponding $\mathrm{C}$-acylated derivatives were obtained by reaction of aromatic carboxylic acid chlorides with 4-thio-3-methylrhodanine. That the compound existed in the enthiol or thioketone form or the mixture of these two forms is based on the study of ${ }^{1} \mathrm{H}-\mathrm{NMR}$ spectra (presented in table 1). There was a remark: if the compound presented in thioketoneenol form (A), the hydroxyl group at $\mathrm{C}-6$ chelated with thiocarbonyl $(\mathrm{C}=\mathrm{S})$ resonated at about $15.5 \mathrm{ppm}$. If the product presented in ketone-enthiol form (B), the mercapto group at C-4 chelated with carbonyl $(\mathrm{C}=\mathrm{O})$ resonanced at about $7.00-7.13 \mathrm{ppm}$. Further more, the $\mathrm{N}$ methyl group resonated at about $3.82 \mathrm{ppm}$ relatively in lower field comparing to the one of (B), excepted for $\mathrm{X}=-\mathrm{NO}_{2}$ and $-\mathrm{N}\left(\mathrm{CH}_{3}\right)_{2}$. 
We also observed that there is a enthiol - thioketone tautomerism between product (A) and (B). The different substituents at the para-position of aromactic ring affect on the percentage of $(\mathrm{A})$ and $(\mathrm{B})$ in the mixture products. Especially, if $\mathrm{X}$ is $-\mathrm{F}$ or $-\mathrm{CF}_{3}$, the product appeared completely in the form of thioketone (A). In contrast if $\mathrm{X}$ is $-\mathrm{OCH}_{3}$ or $-\mathrm{C}\left(\mathrm{CH}_{3}\right)_{3}$, the product is totally enthiol form (B).

\section{EXPERIMENTAL}

\subsection{Synthesis of 3-methylrhodanine}

Methyl isothiocyanate $(60.1 \mathrm{~g}, 0.5 \mathrm{~mol})$ and ethyl mercaptoacetate $(36.5 \mathrm{~g}, 0.5 \mathrm{~mol})$ were mixed in a $250 \mathrm{ml}$ conical flask, and then added 10 drops of piperidine. The reaction mixture was stirred for 2 hours at room temperature. After that the reaction flask was put in a refrigerator for 24 hours. No crystal was precipitated, so a solution of water: ethanol (1:1) $(50 \mathrm{ml})$ was added, and the mixture was refluxed for 1 hour. The color changed from yellow to orange-red. The solution was cooled to get crystalline products. After isolating by filtration, the product was recrystallized from ethanol.

3-Methylrhodanine: orange-red solid (mp 69.0-69.5 $\left.{ }^{\circ} \mathrm{C}\right) .{ }^{1} \mathrm{H}-\mathrm{NMR}\left(300 \mathrm{MHz}, \mathrm{CDCl}_{3}\right) \delta$ : $4.01(\mathrm{~s}, 2 \mathrm{H}), 3.38(\mathrm{~s}, 3 \mathrm{H}) .{ }^{13} \mathrm{C}-\mathrm{NMR}\left(300 \mathrm{MHz}, \mathrm{CDCl}_{3}\right) \delta: 201.3(\mathrm{C} 2), 173.7$ (C4), 35.6 (C5) and $31.2(\mathrm{C} 6)$.<smiles>[X]c1ccc(C(=O)C2SC(=S)N(C)C2=S)cc1</smiles><smiles>[X]c1ccc(C(=O)c2sc(=S)n(C)c2S)cc1</smiles>

Scheme 3. Mechanism of synthesis of $\mathrm{C}$-acylation 4-thio-3-methylrhodanine derivatives

\subsection{Synthesis of 4-thio-3-methylrhodanine}

$\mathrm{P}_{2} \mathrm{~S}_{5}(22.23 \mathrm{~g}, 0.1 \mathrm{~mol})$ and anhydrous 1,4-dioxane $(100 \mathrm{ml})$ were mixed in a three-necked flask fitted with a reflux condenser and stirrer. The flask was heated in an oil bath and when 
the temperature in the flask reached $80-90^{\circ} \mathrm{C}, 3$-methylrhodanine $(7.36 \mathrm{~g}, 0.05 \mathrm{~mol})$ was added; the whole was stirred and refluxed at this temperature in 1 hour. The mixture changed from yellow to red. Active charcoal $(1 \mathrm{~g})$ and zinc dust $(2 \mathrm{~g})$ were put into the flask, and the whole was continued refluxing in 15 minutes. The reaction mixture was filtered through a 2centimetre silica gel layer. After evaporating the solution under the reduce pressure, the product was recrystallized from ethanol to get yellowish-orange crystal.

4-Thio-3-methylrhodanine: yellowish-orange solid (mp 101.6 - $\left.102.2{ }^{\circ} \mathrm{C}\right) .{ }^{1} \mathrm{H}-\mathrm{NMR}(300$ $\left.\mathrm{MHz}, \mathrm{CDCl}_{3}\right) \delta: 4.44(\mathrm{~s}, 2 \mathrm{H}), 3.72(\mathrm{~s}, 3 \mathrm{H}) .{ }^{13} \mathrm{C}-\mathrm{NMR}\left(300 \mathrm{MHz}, \mathrm{CDCl}_{3}\right) \delta: 203.7(\mathrm{C} 2), 203.6$ (C4), 46.2 (C5) and 35.7 (C6).

\subsection{C-acylation of 4-thio-3-methylrhodanine derivatives}

Calcium hydroxide $(0.74 \mathrm{~g}, 10 \mathrm{mmol})$ was added to a solution of 4-thio-3methylrhodanine $(0.816 \mathrm{~g}, 5 \mathrm{mmol})$ in anhydrous 1,4-dioxane $(10 \mathrm{ml})$. Then appropriate carboxylic acid chloride $(5 \mathrm{mmol})$ was added with stirring to the mixture. The mixture was heated up slowly on an oil bath. When the temperature rose to $80-95{ }^{\circ} \mathrm{C}$, stirring was continued for another 1.5 hours at this temperature. After reaction, the mixture was poured into $25 \mathrm{ml}$ of $2 \mathrm{M}$ hydrochloric acid. Within some minutes, crystals appeared. The crystals were removed by filtration, washed with water, and recrystallized from ethanol

Table 1. Percentage of $(A)$ and $(B)$ in the mixture products and their ${ }^{1} \mathrm{H}-\mathrm{NMR}$ data

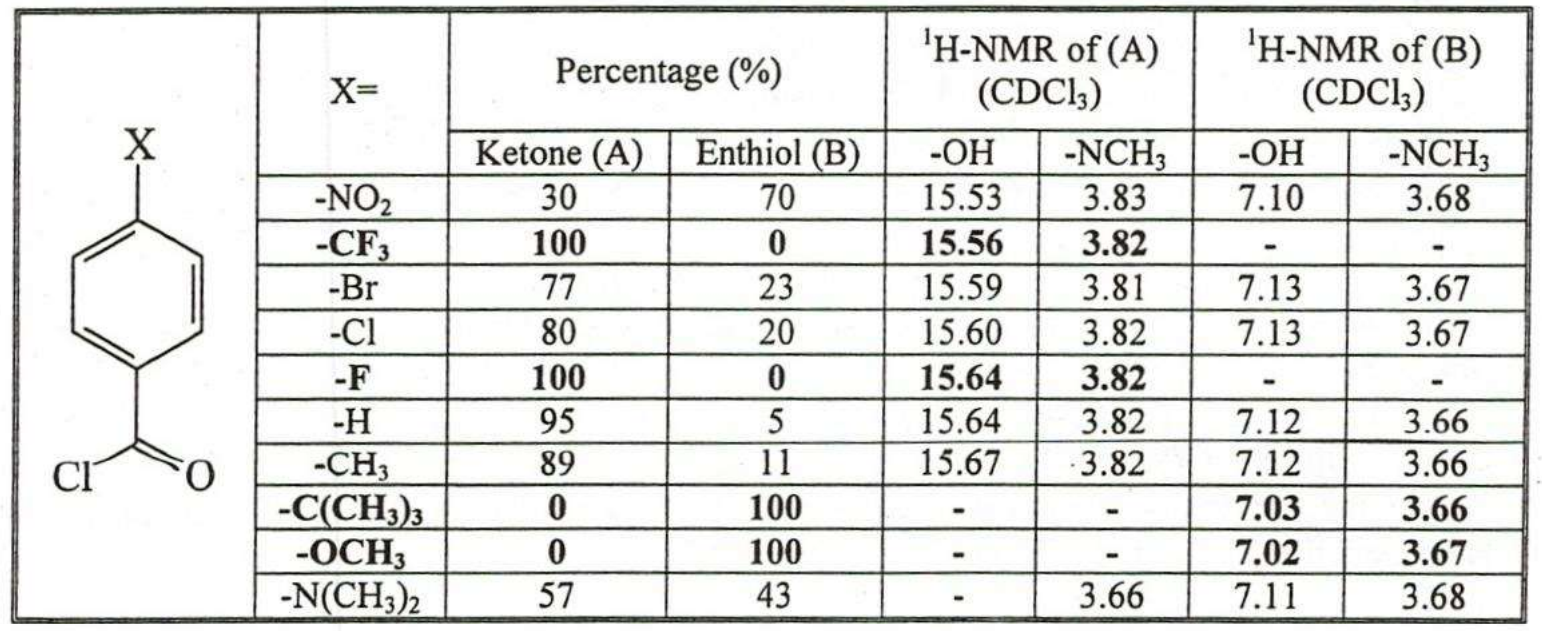

Table 2. ${ }^{13} \mathrm{C}$-NMR data of product (A)

\begin{tabular}{|c|c|c|c|c|c|c|c|c|c|c|}
\hline$X=$ & $C(X)$ & C-2 & $C-3^{\prime}$ & C-4 & C-5 & C- 6 & C-7 & C-8 & C-9 & $C-10$ \\
\hline$-\mathrm{CF}_{3}$ & 123.3 & 193.2 & 34.8 & 187.8 & 111.3 & 165.7 & 137.5 & 128.5 & 126.2 & 133.9 \\
\hline$-\mathrm{Br}$ & & 193.2 & 34.8 & 187.2 & 110.8 & 166.8 & 132.9 & 129.5 & 132.6 & 127.7 \\
\hline$-\mathrm{Cl}$ & & 193.2 & 34.8 & 187.16 & 110.8 & 166.8 & 129.6 & 129.5 & 129.6 & 132.5 \\
\hline$-F$ & & 193.3 & 34.8 & 186.9 & 110.6 & 167.1 & 130.3 & 130.7 & 116.58 & 165.1 \\
\hline$-\mathrm{H}$ & & 193.6 & 34.7 & 186.8 & 110.9 & 168.6 & 134.2 & 128.1 & 129.2 & 132.8 \\
\hline$-\mathrm{CH}_{3}$ & 21.7 & 193.6 & 34.7 & 186.4 & 110.6 & 169.0 & 130.1 & 128.2 & 129.9 & 131.3 \\
\hline$-\mathrm{C}\left(\mathrm{CH}_{3}\right)_{3}$ & $\begin{array}{l}35.2 \underline{\mathrm{C}}\left(\mathrm{CH}_{3}\right)_{3} \\
\left.31.0 \mathrm{C}(\underline{\mathrm{C}})_{3}\right)_{3}\end{array}$ & $\begin{array}{ll}- & -1 \\
-1\end{array}$ & - & - & - & - & - & - & - & - \\
\hline$-\mathrm{OCH}_{3}$ & 55.7 & - & - & - & - & - & - & - & - & - \\
\hline
\end{tabular}




\title{
TỔNG HợP MỘT SỐ DÃ̃N XUÂT TỬ RHODANINES
}

\author{
Ñgô Thị Thùy Dương ${ }^{(1)}$, Nguyễn Tô Nhã ${ }^{(1)}$, Fritz Duus ${ }^{(2)}$, Nguyễn Kim Phi Phụng ${ }^{(1)}$ \\ (1)Trường Đại học Khoa học Tự nhiên, ĐHQG-HCM \\ (2) Đại học Roskilde University, Đan Mạch
}

TÓM TÄT: Hợp chất sulfur thương có hoạt tính sinh học hấp dẫn nên gần đây loại hợp chất này được các nhà hoá học rất quan tâm. Trong báo cáo này chúng tôi tổng hợp một số hợp chất entiol và tioceton tù metyl isotiocyanat và etyl mercaptoacetat thông qua phản úng thio hóa và acyl hóa. Sản phẩm thu nhận được hiện diện ở một trong hai dạng hỗ biển tioceton-enol - ceton-entiol, hoạc ở hôn hợp của hai dạng trên tùy thuộc nhóm thế ở vị trí para của vòng thơm. Việc xác định cấu trúc hóa học của các hợp chất này được thực hiện dựa trên phổ ${ }^{1} H-N M R$ và ${ }^{13} C-N M R$.

\section{REFERENCES}

[1]. Turan Ozturk, Erdal Ertas, Oclay Mert. Use of Lawesson's Reagent in Organic Syntheses. Chem. Rev, 107 (11), 5210 - 5278, (2007)

[2]. Campaigne, E. Chem. ReV., 39, 1, (1946).

[3]. Cava, M. P.; Levinson, M. I. Tetrahedron, 41, 5061, (1985).

[4]. Jesberger, M.; Davis, T. P.; Barner, L. Synthesis 1929, (2003).

[5]. Scheibye, S.; Pedersen, B. S.; Lawesson, S.-O. Bull. Soc. Chim. Belg, 87, 229, (1978).

[6]. Henry, L. Ann. Chem. Pharm., 148, 152, (1869).

[7]. Lecher, H. Z.; Greenwood, R. A.; Whitehouse, K. C.; Chau, T. H. J. Am. Chem. Soc., 78, 5018, (1956).

[8]. Perregaard, J.; Scheibye, S.; Meyer, H. J.; Thomsen, I.; Lawesson, S.-O. Bull. Soc. Chim. Belg., 86, 679, (1977).

[9]. A. P. Grischuk, Azolidine-4-thiones, their derivatives and analogs, Chemistry of Heterocyclic Compounds, 2 (3), 267 - 270, (1967) 


\section{APPENDIX}

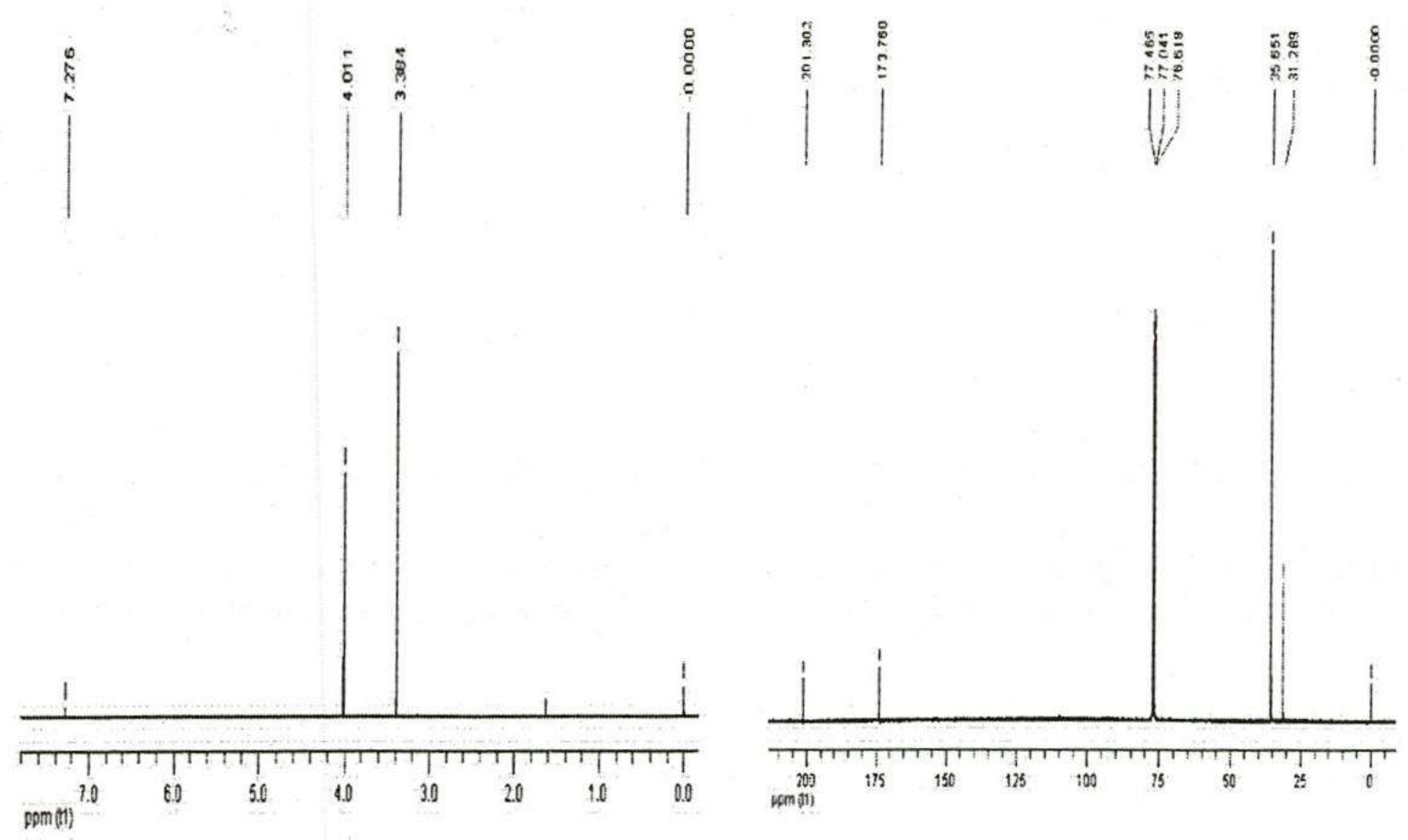

Appendix 1. ${ }^{1} \mathrm{H}$ and ${ }^{13} \mathrm{C}$-NMR spectra of 3-methylrhodanine
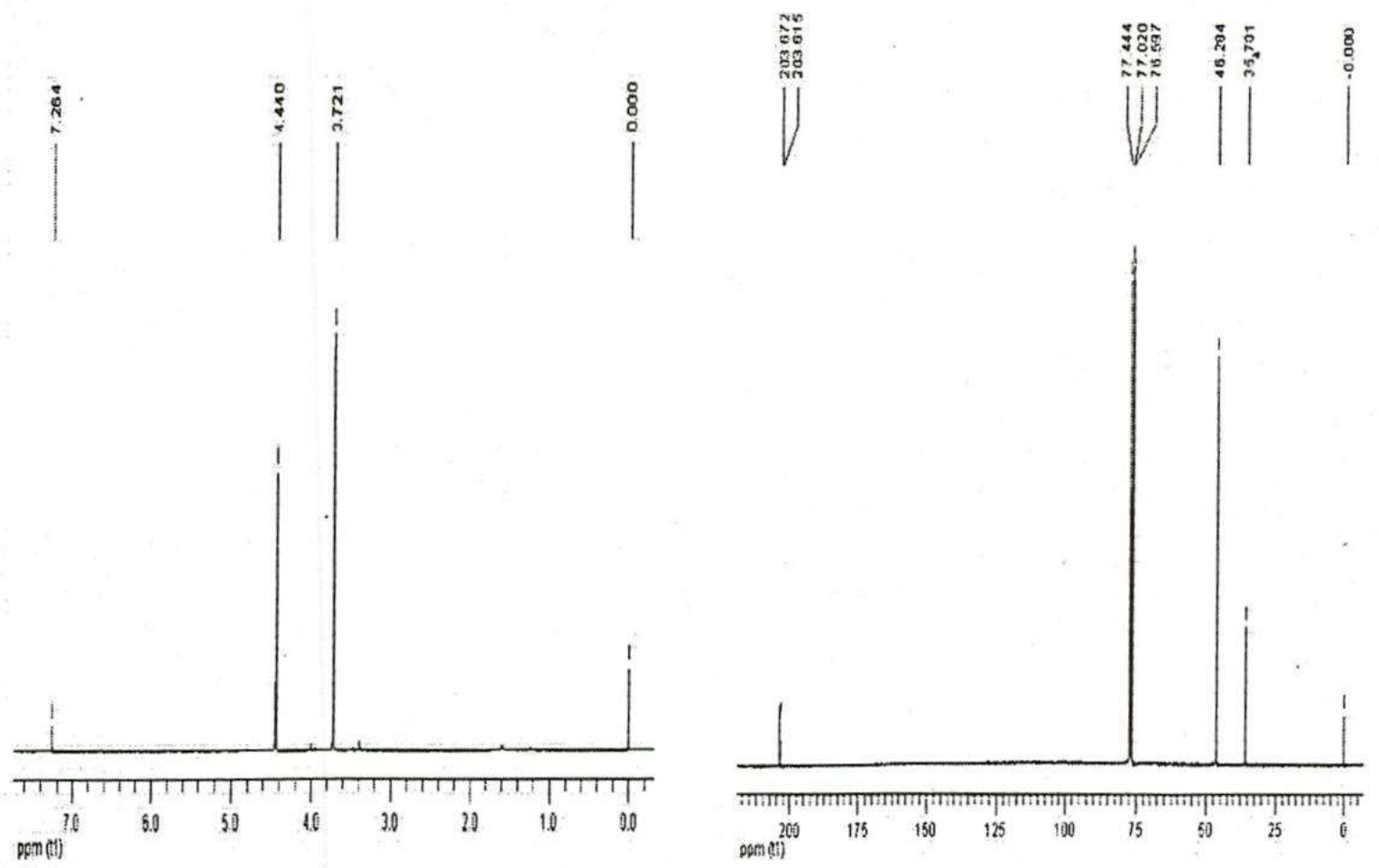

Appendix 2. ${ }^{1} \mathrm{H}$ and ${ }^{13} \mathrm{C}$-NMR spectra of 4-thio-3-methylrhodanine 


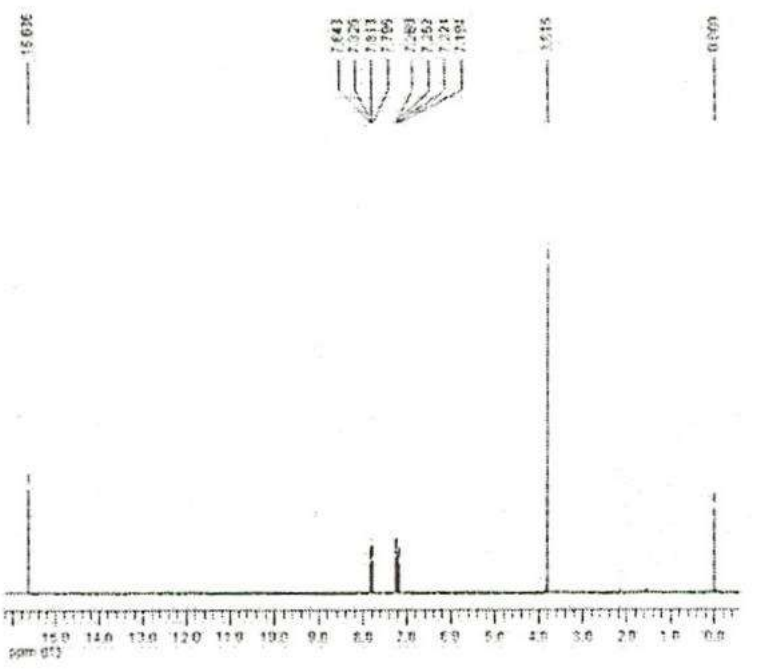

Appendix 3. ${ }^{1} \mathrm{H}-\mathrm{NMR}$ spectrum of thioketone form corresponding to substituent $\mathrm{X}=-\mathrm{F}$.
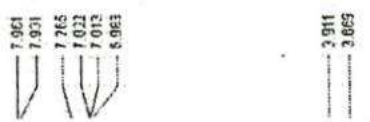

๕

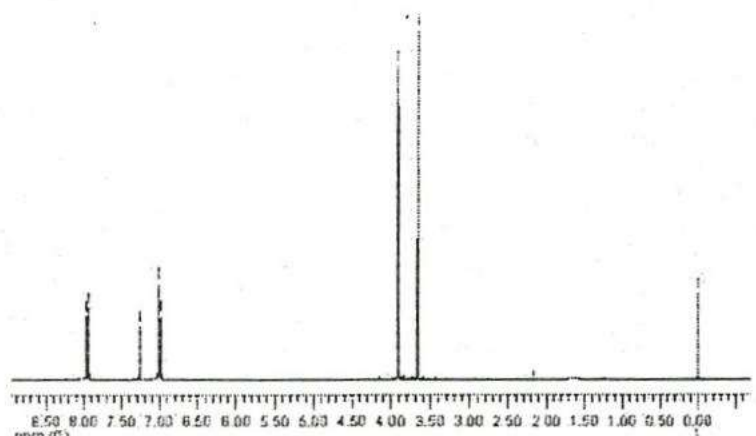

Appendix 4. ${ }^{1} \mathrm{H}-\mathrm{NMR}$ spectrum of enthiol form corresponding to substituent $\mathrm{X}=-\mathrm{OCH}_{3}$. 